Cytogenetic Characteristics of Microtus guentheri, Microtus arvalis sensu lato and Microtus majori (Mammalia: Rodentia) From Turkey: Constitutive Heterochromatin Distribution

Ahmet Yesari SELÇUK ${ }^{1}$, Mehmet Akif BİLİR 2 , Haluk KEFELİOĞLU3

Department of Biology, Faculty of Science, Ondokuz Mayis University, 55200. Samsun- Turkey

${ }^{1}$ https://orcid.org/0000-0002-2785-2823, ${ }^{2}$ https://orcid.org/0000-0002-6835-9154, ${ }^{3}$ https://orcid.org/0000-0002-7421-6037

$\bowtie$ : ahmetyesari@gmail.com

\begin{abstract}
Conventionally stained and C- banded karyotypes of Guenther's vole (Microtus guentheri), Major's pine vole (Microtus majori) and Common vole (Microtus arvalis) were studied from Turkey. Diploid chromosome numbers of $M$. guentheri, $M$. arvalis and $M$. majori were found as $2 \mathrm{n}=54$ and $\mathrm{NFa}=52,2 \mathrm{n}=46$ and $\mathrm{NFa}=68$ and $2 \mathrm{n}=54$ and $\mathrm{NFa}=56$, respectively. All chromosomes of $M$. guentheri were pericentromeric C- band. In Microtus arvalis (obscurus cytotype) and Microtus majori karyotypes, autosomal chromosomes were heterochromatin $\mathrm{C}$ band positive and negative band. In $M$. arvalis (obscurus cytotype), sex chromosome was C band negative. In this study, heterozygote chromosome was not found in the obtained autosomal chromosome set of $M$. arvalis. $M$. majori has enlarged heterochromatin block from centromere to telomere on the long arm of X chromosome. Y chromosome was completely heterochromatin.
\end{abstract}

Research Article

$\begin{array}{ll}\text { Article History } & \\ \text { Received } & : 20.03 .2019 \\ \text { Accepted } & : 05.08 .2019\end{array}$

Keywords

Common vole

C- banding

Guenther's vole

Major's pine vole

Obscurus cytotype

\title{
Microtus guentheri, Microtus arvalis ve Microtus majori (Mammalia: Rodentia) Türlerinin Sitogenetik Özellikleri: Konstitütif Heterokromatin Dağılımı
}

\section{ÖZET}

$\mathrm{Bu}$ çalışmada, Güentheri tarla faresi (Microtus guentheri), Kısa kulaklı kır faresi (Microtus majorı) ve Yaygin tarla faresi (Microtus arvalis) türlerinin standart karyotipleri ve kromozomların C-bant özellikleri belirlendi. $M$. guentheri türünün diploid kromozom sayısı $(2 \mathrm{n})=54$ ve otozomal kromozomların kol sayısı $(\mathrm{NFa})=52, M$. arvalis (obscurus sitotip) türünün $2 \mathrm{n}=46$ ve $\mathrm{NFa}=68$, M.majori türünün $2 \mathrm{n}$ $=54$ ve $\mathrm{NFa}=56$ şeklindedir. $M$. guentheri otozomal ve eşey kromozomlarda pericentromerik C-bant olduğu belirlendi. Microtus arvalis (obscurus sitotip) ve Microtus majori karyotiplerinde otozomal kromozomlar $\mathrm{C}$ bant pozitif ve negatif şeklindedir. $M$. arvalis türünde $\mathrm{X}$ ve $\mathrm{Y}$ kromozomu $\mathrm{C}$ bant negatif özelliktedir. $M$. majori karyotipinde $\mathrm{X}$ kromozomunun uzun kolunda sentromerden telomere doğru genişlemiş heterokromatin blok bulunmaktadır. Y kromozomu ise tamamen heterokromatindir.

\section{Araştırma Makalesi}

$\begin{array}{ll}\text { Makale Tarihçesi } \\ \text { Geliş Tarihi } & : 20.03 .2019 \\ \text { Kabul Tarihi } & : 05.08 .2019\end{array}$

\section{Anahtar Kelimeler}

C-bantlama

Guenther tarla faresi

Kısa kulaklı kır faresi

Obscurus sitotip

Yaygin tarla faresi

To Cite : Selçuk AY, Bilir MA, Kefelioğlu H 2019. Cytogenetic Characteristics of Microtus guentheri, Microtus arvalis sensu lato and Microtus majori (Mammalia: Rodentia) From Turkey: Constitutive Heterochromatin Distribution. KSU J. Agric Nat 22(Suppl 2): 395-400. DOI: 10.18016/ksutarimdoga.vi.542371.

\section{INTRODUCTION}

Microtus is the most branched species genus among the rodents distributed in the Palearctic (Shenbrot and Krasnov, 2005). It is very difficult to morphologically distinguish the Microtus, which is represented by 65 species, from each other (Musser and Carleton, 1993; Jaarola et al., 2004). However, they are frequently used in comparative cytotaxonomy studies since they differ from each other in terms of diploid chromosome numbers $(2 \mathrm{n}=17-62)$ despite their morphological similarities (Zima and Král, 1984; Modi, 1987;
Zagorodnyuk, 1990; Lemskaya et al., 2010). Twelve of the vole species, $M$. dogramacii, $M$. anatolicus, $M$. hartingi, $M$. levis, $M$. arvalis, $M$. subterraneus, $M$. daghestanicus, M. irani, M. schidlovskii, M. majori, $M$. guentheri and $M$. socialis have been reported from Turkey (Jaarola et al., 2004; Kryštufek and Vohralik, 2005; Kryštufek et al., 2012; Arslan et al., 2016; Selçuk and Kefelioğlu, 2018; Demirtaş and Gürler, 2019). These species distributed in Turkey are classified in three main groups as 'pine voles', 'social voles' and 'arvalis group' (Kryštufek and Vohralik, 2005). 
According to Tougard et al., (2013) in the Microtus arvalis sensu lato, cytogenetic studies revealed that there were two distinct cytotypes in the Microtus arvalis sensu lato; the common (arvalis cytotype) and Altai (obscurus cytotype) voles. These cytotypes were attributed to the common (arvalis) and Altai (obscurus) voles having, respectively, fundamental number of autosomes $(\mathrm{NFa})=80$ in Caucasian populations; $\mathrm{NFa}=68-70$ (Meyer et al., 1996). Within the distribution areas of populations of $M$. majori, $M$. guentheri and obscurus cytotype, various researchers have conducted karyological studies in the form of conventional chromosome staining (Kefelioğlu, 1995; Çolak et al., 1997a, b; Çolak et al., 1998; Kefelioğlu and Kryštufek, 1999; Yiğit and Çolak, 2002; Arslan and Zima, 2014), G- banding (Macholan et al., 2001; Zima et al., 2013), C and Ag-NOR banding (Yiğit and Çolak, 2002; Baydemir et al., 2011; Tougard et al.,2013; Yorulmaz et al., 2013; Zima et al., 2013). According to these studies, variations was found in the autosomal and sex chromosome morphologies of $M$. guentheri, $M$. arvalis (obscurus cytotype) and M. majori species.

The objective of this study was to compare the conventional karyotypes of $M$. majori, $M$. guentheri and $M$. arvalis (obscurus cytotype) species and their constitutive heterochromatin regions, which is a karyotypic characteristic, with previously conducted studies and thus contribute to future karyological studies.

\section{MATERIAL and METHOD}

Chromosome preparations were obtained from the femoral bone marrow cells of colchicine treated animals (Ford and Hamerton, 1956). Two samples (two females) of $M$. guentheri species were obtained from Tokat province (N40 21'-E36 $37^{\circ}$ ', Central Anatolia), two samples (two males) of $M$. majori species were

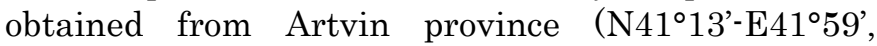
Northeast Anatolia, Caucasia region) and one sample of $M$. arvalis (obscurus cytotype) was obtained from Ardahan-Kars border province (N40 $48^{\prime}-\mathrm{E} 42^{\circ} 52^{\prime}$, Northeast Anatolia) by using live animal traps. Diploid chromosome number (2n) and fundamental number of autosomal arms (NFa) and sex chromosomes of small mammals used in the study were defined as metacentric, acrocentric, submetacentric and subtelocentric. The constitutive heterochromatin distribution was determined by using techniques from Summer (1972). From each specimen, 10 to 20 slides were prepared and at minimum of 10 well-spread metaphase plates were analysed. Karyotype slides and chromosome-fixative solution, which did not undergo diffusion procedure, are being kept at Ondokuz Mayis University Cytogenetic Laboratory under -20 degrees for future studies.

\section{RESULT}

Karyotype is $2 \mathrm{n}=54$ and $\mathrm{NFa}=52$ in Tokat samples of $M$. guentheri. The karyotype has 26 pairs of acrocentric autosomal chromosome in different sizes (chromosomes no: 1-26). In sex chromosomes, X chromosome is large subtelocentric. In the $\mathrm{C}$-banding pattern of $M$. guentheri, positive constitutive heterochromatins are in centromere region. The $\mathrm{X}$ chromosome is positive $\mathrm{C}$-band (Figure 1).
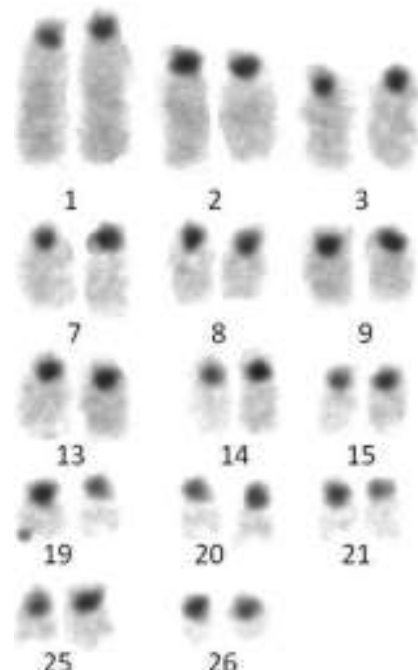
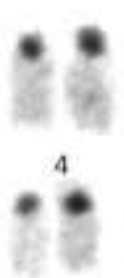

10

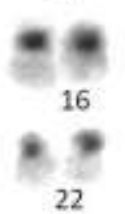

22

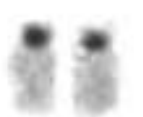

5

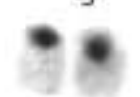

11

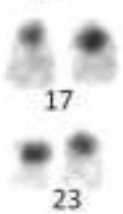

23

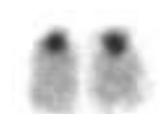

6

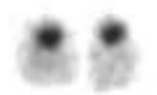

12

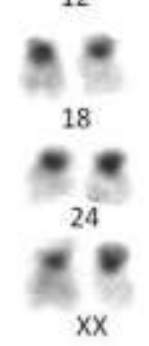

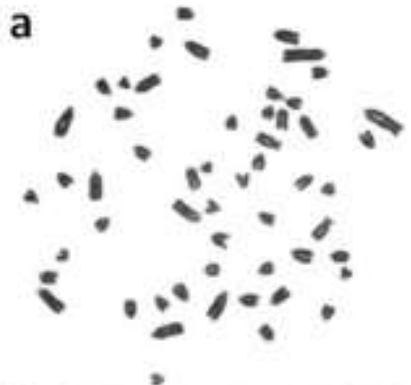

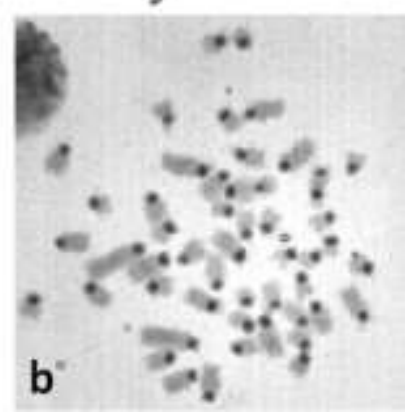

Figure 1. Metephase plate (a) and C-banded karyotype (b) of Microtus guentheri (female) from Tokat (Central Anatolia) 
Karyotype is $2 \mathrm{n}=46$ and $\mathrm{NFa}=68$ in Kars sample of $M$. arvalis (obscurus cytotype). The karyotype has four pairs of different sizes of metacentric and submetacentric (chromosomes no: 1-4), one pair of subtelocentric (chromosome no: 5), seven pairs of small metacentric and submetacentric (chromosomes no: 612) and 10 pairs of different sizes of acrocentric (chromosomes no: 13-22) autosomal chromosome. The $\mathrm{X}$ chromosome is large metacentric and the $\mathrm{Y}$ chromosome is small metacentric (Figure 2).
The karyotype has positive and negative constitutive heterochromatin. While small two-armed chromosomes (chromosomes no: 6-11) have pericentromeric $\mathrm{C}$ - positive banding pattern, only chromosomes: 13-15-16-19-22 have pericentromeric Cpositive banding pattern in acrocentric chromosomes. Sex chromosomes ( $\mathrm{X}$ and $\mathrm{Y}$ ) are $\mathrm{C}$ - band negative (Figure 3).

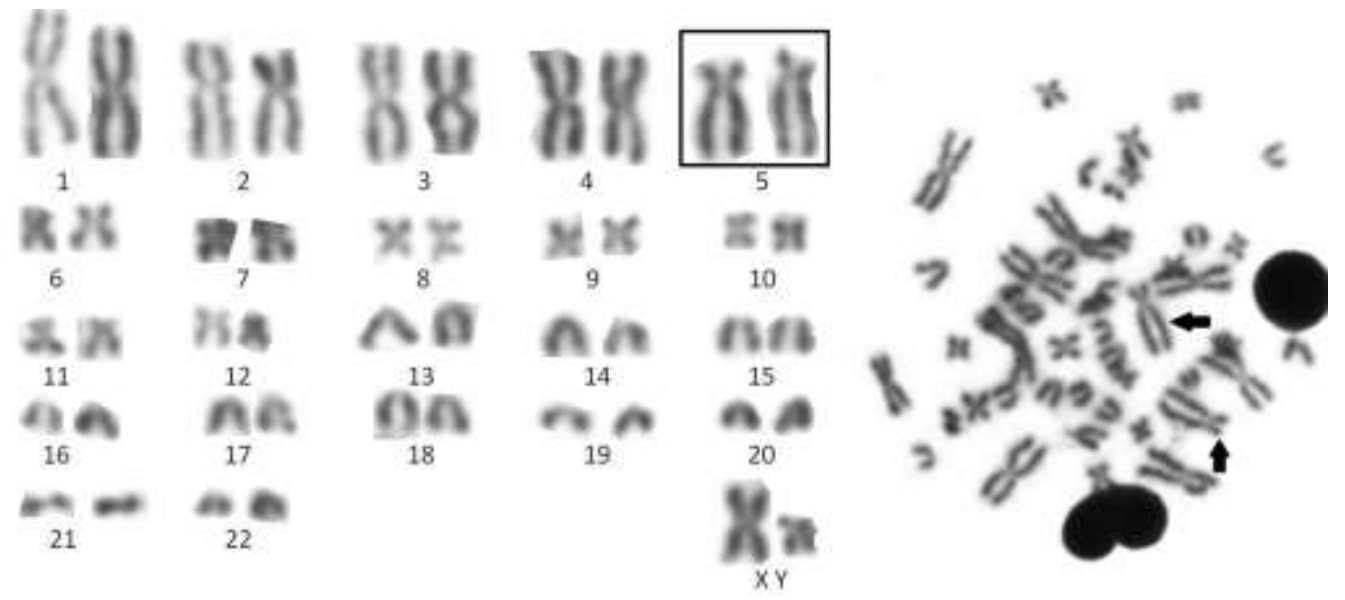

Figure 2. Conventional karyotype and metaphase plate of $M$. arvalis (obscurus cytotype) (male) from Kars. In box: Homomorphic subtelocentric autosomal chromosome, arrows: homomorphic subtelocentric chromosome

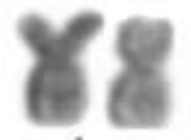

1

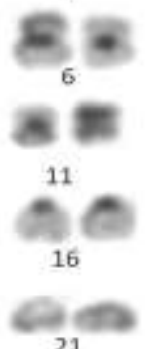

21

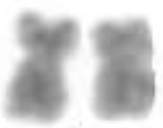

2

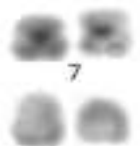

12

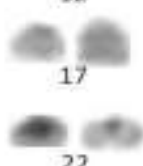

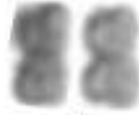

3

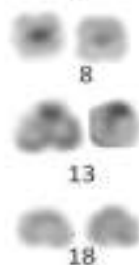

18
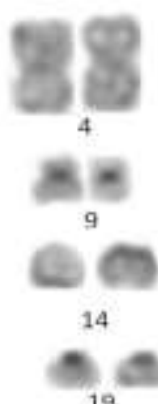

19
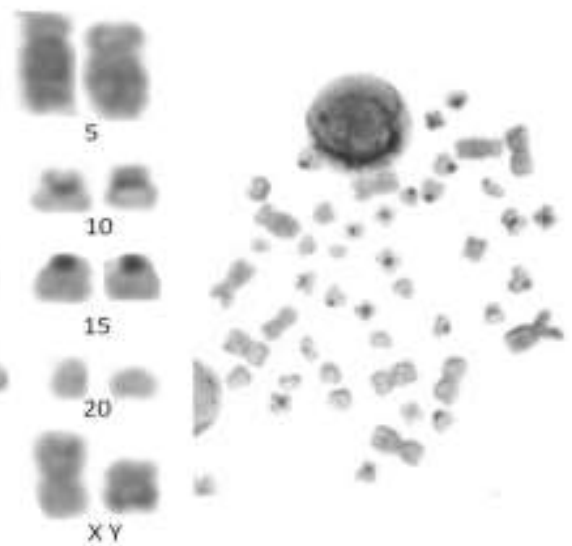

Figure 3. C-banded karyotype and metaphase plate of $M$. arvalis (obscurus cytotype)

In Microtus majori Artvin samples, the karyotype is $2 \mathrm{n}=54, \mathrm{NFa}=56$. While $\mathrm{X}$ chromosome is large submetacentric, $\mathrm{Y}$ chromosome is acrocentric (Figure 4). The karyotype has two pairs of submetacentric (chromosomes no: 1-2) and 24 pairs of acrocentric autosomal chromosome (chromosomes no: 3-26). The karyotype has positive (chromosomes no: 2, 3, 4, 8, 20, 22,25 ) and negative C- banding pattern (Figure 4 ). The long arm of the $\mathrm{X}$ chromosome has heterochromatin block enlarged from centromere to telomere. The Y chromosome is completely heterochromatin (Figure 4).

\section{DISCUSSION}

Microtus guentheri karyotype $(2 \mathrm{n}=54)$ was found to be compatible in similar with the studies conducted in the Anatolia and neighbouring regions (Kefelioğlu, 1995; Baydemir et al., 2011; Zima et al., 2013). M. guentheri shows variations in terms of sex chromosome morphology (X=acrocentric, metacentric, submetacentric, subtelocentric). $\mathrm{X}$ chromosome is metacentric in studies conducted in South Anatolia (Colak et al., 1997a) and in various regions of Anatolia 
(Kefelioğlu, 1995; Yiğit and Çolak, 2002); acrocentric in studies conducted in Central and Southern Anatolia (Çolak et al., 1998; Baydemir et al., 2011); submetacentric in studies conducted in Central Anatolia (Baydemir et al., 2011); and subtelocentric in Southern Anatolia and Syria population (Zima et al., 2013) and the present study (central Anatolia). Constitutive heterochromatin distribution is homomorphic and pericentromeric in autosomal chromosomes (O'Brien, 2006; Baydemir et al., 2011;
Zima et al., 2013; in this study). In Harput (Southern Anatolia) samples, while the short arm of the $\mathrm{X}$ chromosome consists of completely heterochromatin block (Zima et al., 2013), constitutive heterochromatin is in the pericentromeric region of subtelocentric or submetacentric X chromosome in Central Anatolia sample (Nevşehir samples, Baydemir et al., 2011; Konya samples, Zima et al., 2013; Tokat samples in the present study).

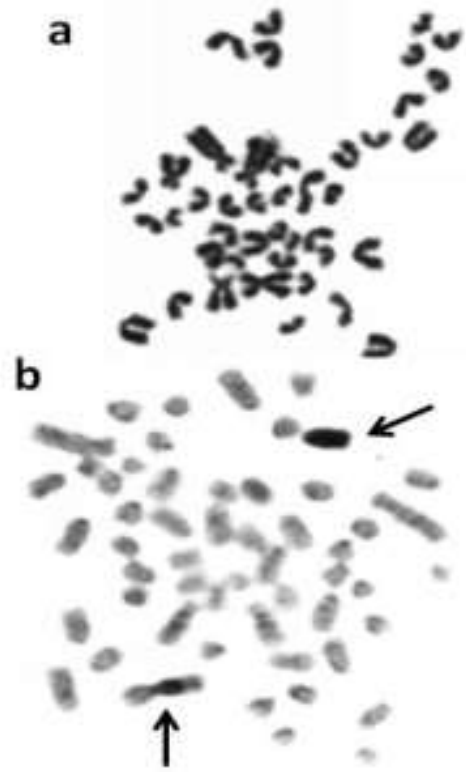

Figure 4. Metephase plate (a) and C-banded karyotype (b) of Microtus majori (male) from Artvin (Northeast Anatolia, Caucasia region). Arrows: X and Y chromosome

In terms of $M$. arvalis (obscurus cytotype) diploid chromosome number, this study was similar to previously conducted (Zima and Král, 1984; Kefelioğlu, 1995; Yorulmaz et al., 2013) studies. However, due to pericentric inversion, NFa number can differ (Gileva and Rakitin, 2006; Baskevich et al., 2016). Due to pericentric inversion, there may be one pair of the heteromorphic chromosome (subtelocentric and acrocentric) in autosomal chromosome set of obscurus cytotype (Gileva and Rakitin, 2006; Yorulmaz et al., 2013; Baskevich et al., 2016). In this study, (chromosome no: 5) and in Kefelioğlu (1995)'s study conducted in Turkish populations, heterozygote chromosome was not found in the obtained autosomal chromosome set. However, Heteromorphic chromosome was found in the Artvin (Turkey) sample (Yorulmaz et al., 2013). While X chromosome is metacentric in obscurus cytotype (Zima and Král, 1984; Kozlovskii et al., 1988; Kefelioğlu 1995; Tougard et al., 2013; Yorulmaz et al., 2013; Baskevich et al., 2016), variations can be seen in the centromere position of Y chromosome (Baskevich, 1996). While Y chromosome was found to be acrocentric in a study conducted in Turkey by Kefelioğlu (1995) and in Chinese by Tougard et al., (2013), it is metacentric in the present study. Constitutive heterochromatin distribution generally shows negative C- banding pattern in autosomal chromosomes and this is similar to a study conducted by Yorulmaz et al., (2013) from Turkey. In addition, $\mathrm{X}$ chromosome has negative $\mathrm{C}$ banding pattern in our study.

Microtus majori diploid chromosome number and sex chromosome morphology was similar in the studies conducted previously in Turkey and Caucasia (Zima and Král, 1984; Macholan et al., 2001; O’Brien, 2006; Kuliev and Bickham, 2010; Arslan and Zima, 2014; Baskevich et al., 2015). As an exception to this result, in studies conducted by Colak et al., (1997b) on samples of $M$. majori species, X chromosome was reported to be subtelocentric. While constitutive heterochromatin distribution is obscurely $\mathrm{C}$ - positive banded in autosomal chromosomes, autosomal chromosomes are generally $\mathrm{C}$ - negative banded. A similar result was found in a study conducted by Kuliev and Bickham (2010) on the Greater Caucasus Mountains and Lesser Caucasia Mountains. Autosomal chromosome set generally shows C- band negative characteristic (Kuliev and Bickham, 2010; in this study). A wide heterochromatin block extending down the centromere from the long arm of the $\mathrm{X}$ 
chromosome is similar to samples obtained from Greater Caucasus Mountains by Kuliev and Bickham (2010) and samples obtained by Macholan et al., (2001) from Turkey. However, in samples obtained from Lesser Caucasia Mountains, there was not a wide heterochromatin block in the long arm of the $\mathrm{X}$ chromosome (Kuliev and Bickham, 2010). The Y chromosome consists of completely heterochromatin block in both Caucasian and Turkish population (Macholan et al., 2001; Kuliev and Bickham, 2010; in this study).

\section{ACKNOWLEDGEMENT}

This study was conducted after permission was obtained from the Ondokuz Mayis University Local Ethics Committee for Animal Experiments (permission number: B.30.2.ODM.0.20.09.00-050.0456). The wild animals used in the study were obtained within the scope of 'National Biological Variation Inventory and Monitoring Project (UBENIS)' conducted by the Ministry of Forestry and Water Management. We would like to thank the employees in the Ministry of Forestry and Water Management Kars branch Office for their contribution in the field studies.

\section{REFERENCES}

Arslan A, Zima J 2014. Karyotypes of the mammals of Turkey and neighbouring regions: review. Folia Zoologica 63: 1-62.

Arslan A, Toyran K, Gözütok S, Yorulmaz Y, Zima J 2016. Comparison of the chromosome banding patterns in three species of social voles (Microtus irani karamani, M. schidlovskii, M. anatolicus) from Turkey. Turkish journal of Zoology, 40: 910916.

Baskevich MI 1996. On the karyological differentiation in Caucasian populations of common vole (Rodentia, Cricetidae, Microtus). Zoologicheskiı zhurnal. 75: 297-308. (in Russian with English summary).

Baskevich MI, Potapov SG, Khlyap LA, Okulova NM, Ashibokov UM, Grigoriev MP, Dzagurova TK 2015. Chromosomal and molecular investigations of cryptic species of the subgenus Terricola (Rodentia, Arvicolinae, Microtus) in the Caucasian region: Analysis of new records. Zoologicheskiǐ zhurnal. 94 (8): 963-971.

Baskevich MI, Mironova TA, Cherepanova EV, Krivonogov DM 2016. New Data on Chromosomal Variability, Distribution of Sibling Species, and Hybridization of 46-Chromosomal Forms of Microtus arvalis sensu lato (Rodentia, Arvicolinae) in the Upper Volga Basin. Biology Bulletin, 43 (9): 1281-1291.

Baydemir AN, Albayrak I, Gözütok S 2011. Cytogenetic study on Microtus guentheri (Danford \& Alston, 1880) (Mammalia: Rodentia) from Turkey: constitutive heterochromatin distribution and nucleolar organizer regions. Folia Biologica (Kraków), 59: 35-40.

Çolak E, Yiğit N, Sözen M, Özkurt Ş 1997a. Distribution and taxonomic status of the genus Microtus (Mammalia: Rodentia) in Southeastern Turkey. Israel Journal of Zoology, 43: 391-396.

Çolak E, Yigit N, Sözen M, Özkurt Ş 1997b. A study on taxonomic status of Microtus subterraneus (de Selys Longchamps, 1836) and Microtus majori Thomas, 1906 (Mammalia: Rodentia) in Turkey. Turkish Journal of Zoology, 22: 119-129 (in Turkish with English summary).

Çolak E, Sözen M, Yiğit N, Özkurt Ş 1998. A study on ecology and biology of Microtus guentheri Danford and Alston, 1880 (Mammalia: Rodentia) in Turkey. Turkish Journal of Zoology, 22: 289-295.

Demirtaş S. Gürler AT 2019. New records of the Iranian Vole, Microtus irani Thomas, 1921, from eastern Turkey (Mammalia: Rodentia). Zoology in the Middle East, 65: 91-94.

Ford CE, Hamerton JL 1956. 'A colchicine-hypotoniccitrate' squash sequence for mammalian chromosomes. Stain Technology, 31: 247-251.

Gileva EA, Rakitin SB 2006. Factors of Maintaining Chromosome Polymorphism in Common Vole Microtus arvalis Pallas, 1779: Reduced Fertility and Meiotic Drive. Russian Journal of Genetics, 42 (5): 498-504.

Jaarola M, Martínková N, Gündüz I, Brunhoff C, Zima J, Nadachowski A, Amori G, Bulatova NS, Chondropoulos B, Fraguedakis-Tsolis S, GonzálezEsteban J, López-Fuster MJ, Kandaurov AS, Kefelioğlu H, Mathias ML, Villate I, Searle JB 2004. Molecular phylogeny of the speciose vole genus Microtus (Arvicolinae, Rodentia) inferred from mitochondrial DNA sequences. Molecular Phylogenetics and Evolution, 33: 647-663.

Kefelioğlu H 1995. The taxonomy of the genus of Microtus (Mammalia: Rodentia) and its distribution in Turkey. Turkish Journal of Zoology, 19: 35-63. (in Turkish with English summary).

Kefelioğlu H, Kryštufek B 1999. The taxonomy of Microtus socialis group (Rodentia: Microtinae) in Turkey, with the description of a new species. Journal of Natural History, 33: 47-67.

Kozlovskii AI, Bulatova NS, Novikov AD 1988. Double effect of an inversion in the karyotype of common vole. Doklady AN SSSR 298: 994-997 (in Russian).

Kryštufek B, Vohralik V 2005. Mammals of Turkey and Cyprus. Rodentia I: Sciuridae, Dipodidae, Gliridae, Arvicolinae. Založba Annales, Koper, Slovenia, $292 \mathrm{pp}$.

Kryštufek B, Zorenko T, Buzan VE 2012. New insights into the taxonomy and phylogeny of social voles inferred from mitochondrial cytochrome $b$ sequences. Mammalian Biology, 77: 178-182.

Kuliev G, Bickham J 2010. Karyological Relationships and Biodiversity of the Pine Voles of Azerbaijan: 
Differentiation of Species from the Greater and Lesser Caucasus Mountains. Occasional Papers, Museum of Texas Tech University, $291 \mathrm{pp}$.

Lemskaya NA, Romanenko SA, Golenishchev FN, Rubtsova NV, Sablina OV, Serdukova NA., O'Brien PCM, Fu B, Yiğit N, Ferguson-Smith MA, Yang F, Graphodatsky AS 2010. Chromosomal evolution of Arvicolinae (Cricetidae, Rodentia). III. Karyotype relationships of ten Microtus species. Chromosome Research, 18: 459-471.

Macholán M, Filippucci MG, Zima J 2001. Genetic variation and zoogeography of pine voles of the Microtus subterraneus / majori group in Europe and Asia Minor. Journal of Zoology, London, 255: 3142 .

Meyer MN, Golenishchev FN, Radjably SI, Sablina OV 1996. Voles (subgenus Microtus Schrank) of Russia and adjacent territories. Proceedings of the Zoological Institute, Russian Academy of Sciences 232: 1-330 (in Russian).

Modi WS 1987. Phylogenetic analyses of chromosomal banding patterns among the Neartic Arvicolidae (Mammalia: Rodentia). Systematic Zoology, 36: 109-136.

Musser GG, Carleton MD 1993. Mammal Species of the World: A Taxonomic and Geographic Reference. Smithsonian Institution Press, Washington, 510$756 \mathrm{pp}$.

O'Brien SJ, Menninger JC, Nash WG 2006. Atlas of mammalian chromosomes. Wiley, Hoboken, 714 pp.

Selçuk AY, Kefelioğlu H 2018. Cytogenetic characteristic of East European vole Microtus levis and common pine vole Microtus subterraneus (Mammalia: Rodentia) from Turkey: Constitutive Heterochromatin Distribution. Biharean Biologist,
12: 13-16.

Shenbrot GI, Krasnov BR 2005. Atlas of the Geographic Distribution of the Arvicoline Rodents of the World (Rodentia, Muridae: Arvicolinae), Sofia: Pensoft.

Summer AT 1972. A simple technique for demonstrating centromeric heterochromatin. Experimental Cell Research, 75: 304-306.

Tougard C, Montuire S, Volobouev V, Markova E, Contet J, Anıskin V, Quere J 2013. Exploring phylogeography and species limits in the Altai vole (Rodentia: Cricetidae). Biological Journal of the Linnean Society, 108: 434-452.

Yiğit N, Çolak E 2002. On the distribution and taxonomic status of Microtus guentheri (Danford and Alston, 1880) and Microtus lydius Blackler, 1916 (Mammalia: Rodentia) in Turkey. Turkish Journal Zoology, 26: 197-204.

Yorulmaz T, Zima J, Arslan A, Kankılıç T 2013. Variations in the C-heterochromatin and AgNOR distribution in the common vole (Microtus arvalis sensu lato) (Mammalia: Rodentia). Archives of Biological Sciences, Belgrade, 65: 989-995.

Zagorodnyuk IV 1990. Variability and systematics of the Arvicolini (Rodentia). Communication 1. Species and chromosomal numbers. Vestnik Zoologii, 2: 26-37.

Zima J, Král B 1984. Karyotypes of European mammals I. Institute of Landscape Ecology, 18 (7): $1-51$.

Zima J, Arslan A, Benda P, Macholán M, Kryštufek B 2013. Chromosomal variation in social voles: a Robertsonian fusion in the Günther's vole. Acta Theriologica, 58: 255-266. 